\title{
Photosynthetic Response of Soybean to Twospotted Spider Mite (Acari: Tetranychydae) Injury
}

\author{
Adeney de Freitas Bueno ${ }^{*}$, Regiane Cristina Oliveira de Freitas Bueno ${ }^{2}$, Paul David \\ Nabity $^{3}$, Leon George Higley ${ }^{3}$ and Odair Aparecido Fernandes ${ }^{4}$ \\ ${ }^{1}$ Centro Nacional de Pesquisa de Soja; Embrapa-Soja; C. P. 231; 86001-970; Londrina - PR - Brasil. ${ }^{2}$ Bolsista Pós- \\ doutorado Capes PNPD; Universidade de Rio Verde; 75901-970; Rio Verde - GO - Brasil..$^{3}$ Department of \\ Entomology; University of Nebraska-Lincoln; 68583-0816; Lincoln, NE - USA. ${ }^{4}$ Departamento de Fitossanidade; \\ Universidade Estadual Paulista Júlio de Mesquita Filho; 14884-900; Jaboticabal - SP-Brasil
}

\begin{abstract}
The twospotted spider mite Tetranychus urticae Koch is a common pest on soybean plants. To clarify plantarthropod interaction on mite-soybean system, leaf fluorescence, photosynthetic responses to variable carbon dioxide levels, and chlorophyll content were evaluated. Significant photosynthetic rate reduction was observed due to stomatal limitation. Stomatal closure was the major plant physiological response. As a consequence, there was reduction in photosynthetic rates. Surprisingly, plants did not show chlorophyll content reduction associated with photosynthetic impairment. No differences in fluorescence data indicate that T. urticae injury did not impair the function of light harvesting and photoelectron transport. These results showed that T. urticae could be a serious pest of soybean even on lower infestation, at least when photosynthesis was determinant to yield.
\end{abstract}

Key words: Tetranychus urticae, insect-plant relationship, fluorescence, gas exchange, photosynthesis

\section{INTRODUCTION}

Twospotted spider mite, Tetranychus urticae Koch, is a common pest of many crops and is a serious one, yet sporadic, of soybean, Glycine max (L.) Merrill in many soybean-growing areas. Twospotted spider mite can achieve pest status mainly under hot and dry conditions (Ratcliffe et al., 1960) that is favorable for the mite itself and unfavorable for the entomopathogenic fungi (Neozygites) that normally prevents twospotted spider mite outbreaks (Klubertanz et al., 1991). Spider mites feed primarily on leaf surfaces, often occurring in higher numbers on the underside than on the upperside of leaves (Jeppson et al., 1975). The feeding apparatus consists of paired and partially fused cheliceral stylets with which the mite pierces the plants and disrupts mesophyll cells underlying the epidermis (Hislop and Jeppson, 1976). Morphological injury at feeding site is characterized by the punctured and collapsed epidermal cells, a disrupted cuticle, and the cell wall debris of pierced mesophyll cells (Sances et al., 1979; Bondada et al., 1995). Twospotted spider mite stylet length can reach photosynthetically active mesophyll tissue of leaves. Individual cells are damaged; however, even adjacent uninjured cells might show slight symptoms of damage (Park and Lee, 2002). This injury indicates chloroplast destruction. Thus, reductions in chlorophyll content are usually associated with $T$. urticae injury when visible

\footnotetext{
* Author for correspondence: adeney@ cnpso.embrapa.br
} 
damage is present (DeAngelis et al., 1983; Welter, 1989; Campbell and Marini, 1990; Bondada et al., 1995). Little attention has been paid so far to event that happens early at the beginning of infestation or when the level of infestation is low. These specific conditions can help to understand soybean photosynthetic response to $T$. urticae injury. Arthropods, in general, disrupt plant physiological process. How arthropods alter plant physiology has been the focus of lots of work mainly on soybean (Peterson and Higley, 1996; Peterson et al., 1998; Haile and Higley, 2003; Macedo et al., 2003). Alterations in physiological processes (photosynthesis, respiration, stomatal conductance, and transpiration) of plants in response to arthropods feeding are crucial determinants of plant growth, development and fitness (Peterson and Higley, 1993). Establishing these alterations is an important step on further understanding plantarthropods interaction and development of Economic Injury Levels (Peterson and Higley, 2001). Furthermore, arthropods that trigger the same plant physiological response might be grouped into guilds which allows the development of Economic Injury Level for multiple species (Peterson and Higley, 2001).

Physiological response of plants to spider mite injury is described as a reduction in gas-exchange parameters (Ferree and Hall, 1980; Sances et al., 1982a; Sances et al., 1982b; Brito et al., 1986; Candolfi et al., 1992; Lakso et al., 1996; Sadras and Wilson, 1997; Haile and Higley, 2003). However, the mechanisms that trigger this reduction are not yet fully understood. Furthermore, most of the results already accomplished deals with alteration of gasexchange parameters under high mite infestation and long feeding periods (Haile and Higley, 2003). Thus, the threshold when the plant starts showing detectable photosynthetic reduction is not known for most of the crops. Consequently, to study the photosynthetic response of soybean to T. urticae at low levels of infestation and different feeding periods is of both theoretical and practical interest. Presently, no data are available on the relationship between $T$. urticae injury and its effects on soybean leaflet photosynthesis for plants on the vegetative stage. Therefore, the present work aimed to examine the effect of the twospotted spider mite injury on photosynthetic capacity of soybean plants in two different times after growing season (vegetative and reproductive phase). Also, the mechanism by which the photosynthetic system was impaired was analyzed with the aid of fluorescence readings, chlorophyll analyses, and A-Ci curves.

\section{MATERIALS AND METHODS}

\section{Spider mite colony}

A colony of twospottted spider mites was established on soybean cultivar NE3001 planted in $10-\mathrm{cm}$ pots filled with soil-lite $(33 \%$ peat, $30 \%$ perlite, $30 \%$ vermiculite, $7 \%$ soil). Plants and mites were kept in growth chamber at $25 \pm 2{ }^{\circ} \mathrm{C}$ and photophase of 16:8 (L:D). Adults of the mites were individually transferred using camel hair brushes from heavily infested leaflets to $1-\mathrm{cm}^{2}$ leaf discs. These discs were then used to infest the greenhouse and field experiments.

\section{Greenhouse experiment}

Greenhouse experiment was carried out on East Campus of the University of Nebraska, Lincoln, NE, during June and July of 2003. Soybean cultivar NE3001 was planted on June $16^{\text {th }}$ in the pots of one liter of capacity filled with soil-lite (33\% peat, $30 \%$ perlite, $30 \%$ vermiculite, $7 \%$ soil). Plants were watered uniformly from the bottom by placing the pots in plastic trays filled with water. On July $9^{\text {th }}$, when plants were at $\mathrm{V}_{3}-\mathrm{V}_{4}$ growth stage, 24 plants were infested and 24 plants were left as control. In order to infest the plants, each central leaflet belonging to the third fully developed leaf from the top received one- $\mathrm{cm}^{2}$ leaf disc containing 20 adults of spider mites. The mites were confined to the leaflets with the aid of fine-meshed leaf cages. The leaflets of the control treatment also received the cage without infested discs. Cages were removed two days after infestation and the spider mite infestation was isolated to the experimental leaflet ringing the petiole with non-toxic glue (Tangor foot). The treatments (infested and control) were set up on a completely randomized design with 6 replications per treatment per day of evaluation. Gas exchange and fluorescence parameters were measured 3, 6, 9 and 12 days after infestation (DAI). A-Ci curves and chlorophyll content were accounted 9 and 12 days after infestation. 


\section{Field experiment}

Field experiment was carried out simultaneously with the greenhouse experiment on the East Campus of the University of Nebraska, Lincoln. Soybean cultivar NE3001was sowed on May $7^{\text {th }}$ 2003 using a row spacing of $76 \mathrm{~cm}$. Soybeans were infested with two-spotted spider mites at $R_{3}$ growth stage (beginning of pod). Similarly to the greenhouse experiment, leaf discs containing mites from the spider mite colony were used to infest plants. However, since field leaflets were bigger than greenhouse leaflets, a higher number of mites were needed. Each disc contained 50 adult twospotted spider mite. The infested leaflets were enclosed in fine-meshed leaf cages along with leaf discs containing mites in the adult stage. All the cages were sealed with tape in order to avoid the mites to escape. Cages were removed 10 minutes before the evaluation. To investigate any cage effect on plant physiology, two controls were set. Both caged and uncaged control treatments were kept free from mite infestations. Treatment design was a complete randomized block with three treatments (infested, uncaged control, and caged control leaflets) and 5 replications per treatment per day of evaluation. Gas exchange, chlorophyll content, and fluorescence were measured 5 and 10 days after infestation (DAI).

\section{Determination of gas exchange, fluorescence and chlorophyll content}

Gas-exchange, fluorescence, and chlorophyll content were measured at the same soybean leaflets after spider mites were removed. T. urticae were scouted and carefully removed from the soybean leaflets using camel hair brushes. Control treatments were also brushed as well as infested treatments. All the measurements were taken on the same leaflet used for infestation and as a control.

A portable photosynthesis system (Model Licor6400, Li-Cor, Lincoln, NE) with $\mathrm{CO}_{2}$ injector and light source (to allow for stable $\mathrm{CO}_{2}$ and light concentrations) was used to measure gas exchange parameters. The rate of photosynthesis was measured from $6-\mathrm{cm}^{2}$ area, the maximum leaf area measured by the leaf chamber of the LI-6400. The following settings were used: blue light source at $1500 \mu \mathrm{mol} \mathrm{m} \mathrm{m}^{-2} \mathrm{~s}^{-1}$ photosynthetic photon flux density, $400 \mu \mathrm{mol}$ of $\mathrm{CO}_{2} \mathrm{~m}^{-2} \mathrm{~s}^{-1}$, and chamber humidity between $45-55 \%$.
Measurements of fluorescence were taken at darkadapted leaves after 20 minutes of dark adaptation with 'adaption clips'. Readings were made using leaf chamber fluorometer (Model Licor-6400-40, Li-Cor, Lincoln, NE).

Chlorophyll content of soybean leaves was determined in the same leaflets used for gasexchange and fluorescence measures. For this purpose, a chlorophyll meter (Model, Spad-502, Minolta, Japan) was used. Four chlorophyll content measurements were made from each leaflet at different spots. The average of these measurements was used as a replication.

After all the measurements were taken, soybean leaves were collected, leaf images were taken, and the percentage of leaf injury by spider mites was estimated. The whole process was accomplished by the use of a digital camera (model E990, Nikon) and an imaging analysis software (Mocha, Jandel Scientific, San Rafael, CA). A given area was considered injured when it clearly showed necrosis.

\section{Data Analysis}

Data were analyzed using PROC MIXED procedure of the SAS system (SAS Institute, 2001). Means were separated by t-test $(\alpha=0.05)$.

\section{RESULTS AND DISCUSSION}

\section{Greenhouse assays}

Twospotted spider mite caused visible injury to soybean leaves when the plants were in the vegetative stage and as soon as three days after infestation. Both visual symptoms and mite density significantly increased throughout time varying between $13.89 \pm 3.60$ to $100.00 \pm 3.60 \%$ and $0.50 \pm 0.46$ to $6.73 \pm 0.46 \mathrm{mites} / \mathrm{cm}^{2}$, respectively, 3 and 12 days after infestation (Table 1). Even though $94.38 \pm 3.60 \%$ of the area showed visual chlorosis 9 days after the infestation, photosynthetic reductions were noticed only 12 days after the infestation (Fig. 1). However, there was no measurable reduction on chlorophyll content associated with the photosynthetic apparatus impairment (Fig. 2). Chlorophyll content destruction is closely associated with photosynthetic reductions on spider-mite injured plants (Sances et al., 1979; Bondada et al., 1995; Haile and Higley, 2003; Rilling and During, 1990). These findings 
indicated that even before any significant reduction on chlorophyll content could happen, photosynthetic apparatus was impaired somehow. Stomatal conductance, A-Ci curves, and fluorescence values allow to differenciate among stomatal limitation or dark or light reactions impairment, respectively. Then, these measures show exactly which part of the photosynthesis is affected. The results found in this study pointed out to photosynthetic capacity reduction as a consequence of twospotted spider mite infestation due to decreased stomatal conductance (Fig. 3). It showed that the major plant physiological response to $T$. urticae injury was the closure of stomata. Photosynthetic reduction was then a consequence of the stomatal closure and even the chlorophyll content reduction seemed to be a postimpairment event. Similar results were found by Haile and Higley (2003) that also noticed reduction in the chlorophyll content. However, Haile and Higley (2003) worked with a longer feeding period and when the plants were at the reproductive stage.

\section{Field assays}

Differently from the vegetative stage, the soybean leaflets injured by the twospotted spider when the plants were in reproductive stage did not show any visual symptoms and the population did not increase significantly from 5 to 10 days after the infestation (Table 2). Even without any visual symptoms, photosynthetic capacity was impaired by $T$. urticae injury. Plants evaluated 5 and 10 days after twospotted spider mite's infestation only showed photosynthetic reduction 10 days after infestation (Fig. 4). The soybeans leaflets infested with $T$. urticae had no reduction on chlorophyll content in none of the days evaluated (Fig. 5). However, infested leaflets showed the lowest stomatal conductance values (Fig. 6). Thus, similarly to the vegetative stage, stomatal conductance was probably the reason of the photosynthetic apparatus impairment supporting the findings that the stomatal closure was the major plant physiological response to T. urticae stress and photosynthetic reduction was the consequence of this stomatal closure.

Table 1 - Percentage of leaf area showing visual symptoms of feeding injury and number of twospotted spider mite on soybean plant at $\mathrm{V}_{3}-\mathrm{V}_{5}$ stage \pm SEM 3, 6, 9, and 12 days after infestation (DAI).

\begin{tabular}{ccc}
\hline DAI & Injury (\%) & Number of $\mathbf{~ m i t e s} / \mathbf{c m}^{2}$ \\
\hline 3 & $13.89 \pm 3.60 \mathrm{a}$ & $0.50 \pm 0.46 \mathrm{a}$ \\
6 & $41.96 \pm 3.60 \mathrm{~b}$ & $3.15 \pm 0.46 \mathrm{~b}$ \\
9 & $94.38 \pm 3.60 \mathrm{c}$ & $5.10 \pm 0.46 \mathrm{c}$ \\
12 & $100.00 \pm 3.60 \mathrm{c}$ & $6.73 \pm 0.46 \mathrm{~d}$ \\
\hline
\end{tabular}

Means followed by the same letter within a column are not significantly different by t test $(\mathrm{P}>0.05)$.

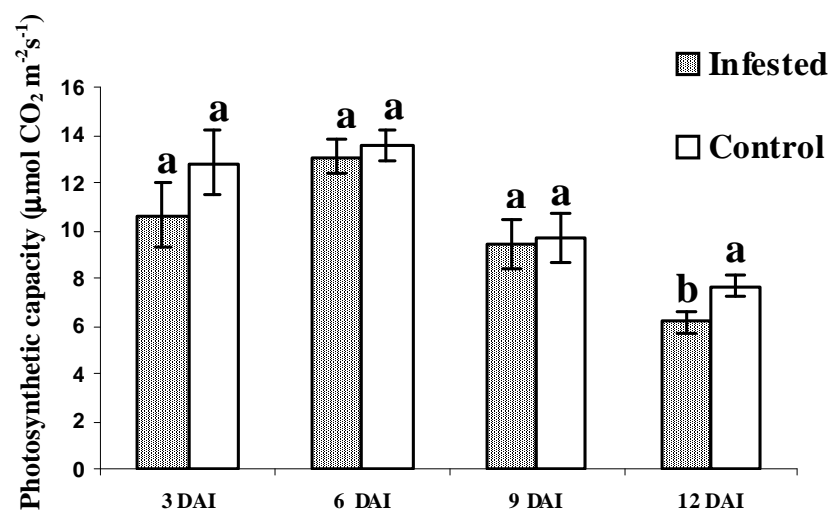

Figure 1 - Photosynthetic capacity $\left(\mu \mathrm{mol} \mathrm{CO}_{2} \mathrm{~m}^{-2} \mathrm{~s}^{-1}\right.$ ) of infested and non-infested soybean plants at $\mathrm{V}_{3}-\mathrm{V}_{5}$ stage \pm SEM after 3, 6, 9, and 12 days after infestation (DAI) with Tetranychus urticae. Means followed by the same letter within a day are not significantly different by $\mathrm{t}$ test $(\mathrm{P}>0.05)$. 


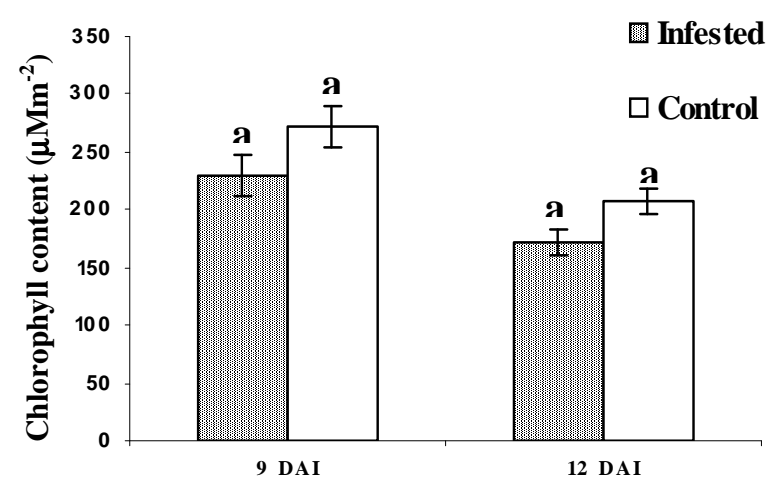

Figure 2 - Chlorophyll content ( $\mu \mathrm{Mm}-2)$ of infested and non-infested soybean plants at V3-V5 stage \pm SEM after 9 and 12 days after infestation (DAI) with Tetranychus urticae. Means followed by the same letter within a day are not significantly different by test $(\mathrm{P}>0.05)$.

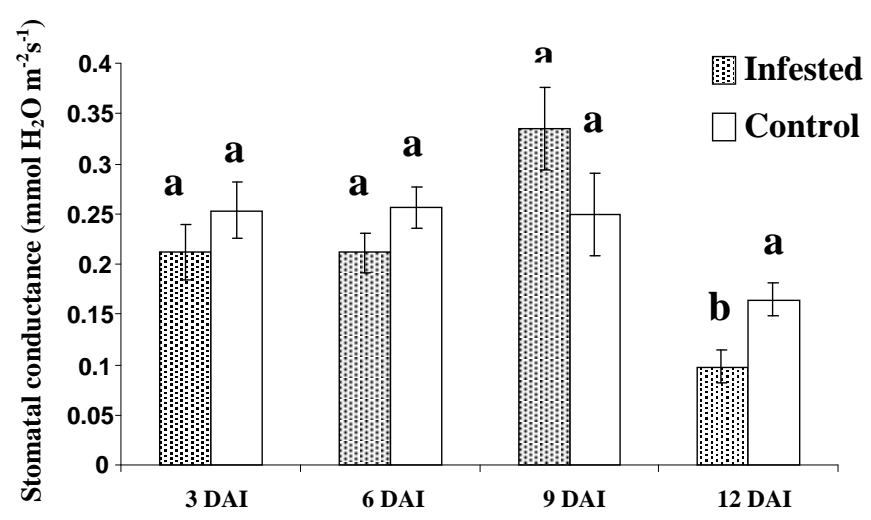

Figure 3 - Stomatal conductance (mmol H2O m-2s-1) of infested and non-infested soybean plants at V3-V5 stage \pm SEM after 3, 6, 9, and 12 days after infestation (DAI) with Tetranychus urticae. Means followed by the same letter within a day are not significantly different by t test $(\mathrm{P}>0.05)$.

Recently, increasing attention has been paid to photoelectron transport as the key to photosynthesis impairment in response to insect injury (Burd and Elliot, 1996; Macedo et al., 2003). While considering that as a valuable hypothesis, distinction between the stomatal limitations in $\mathrm{CO}_{2}$ availability versus mesophyll limitations should be considered. Present results showed that stomatal limitation was an important issue on evaluating T. urticae stress. However, both mesophyll and stomatal limitation together might be leading to photosynthetic reduction. Mesophyll limitations are reductions associated with light-harvesting complexes (light reaction) and/or with $\mathrm{CO}_{2}$ fixation (dark reaction).
Fluorescence measurements indicates the function of light harvesting and photoelectron transport (Macedo et al., 2003). A-Ci curves provide information on rubisco activity and ribulosebiphosphate (RuBP) regeneration in the dark reaction (Farquar et al., 1980). A-Ci curves were run 9 and 12 days after infestation, when the plants were in the vegetative stage, showing no significant differences between the control and infested leaflets in both days (Fig. 7A and B). The similarities in gas exchange parameters for infested and control plants at various $\mathrm{CO}_{2}$ concentrations implied that $T$. urticae injury did not impair the dark reactions. Therefore, rubisco activity and ribulose-biphosphate (RuBP) 
regeneration was not impaired. Data on fluorescence demonstrated the photochemical efficiency in the light reaction center of photosynthesis, primarily the electron transport system in photosystem II. There were no differences in fluorescence readings of soybeans in the vegetative stage at 12 days after infestation (Table 3). The same happened when the plants were in the reproductive stage at 10 days after infestation (Table 4). These findings indicated that T. urticae injury did not impair the function of light harvesting and photoelectron transport.

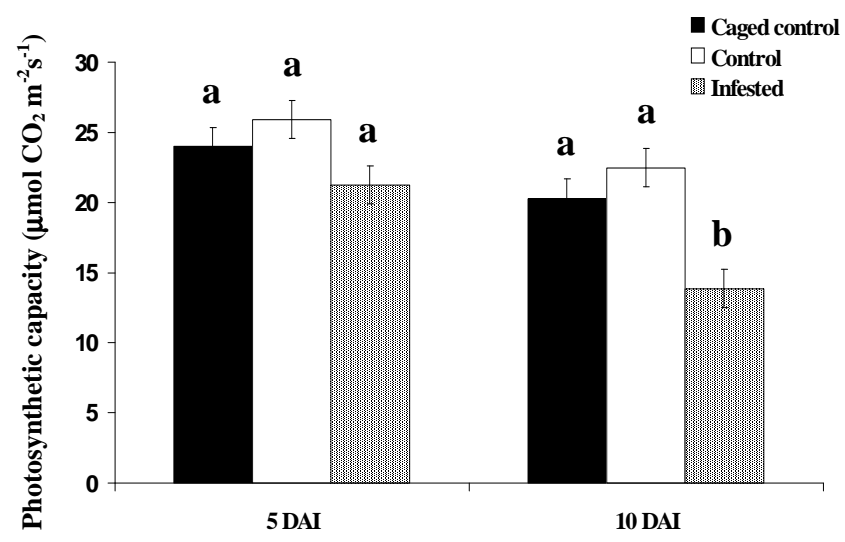

Figure 4 - Photosynthetic capacity ( $\mu$ mol CO2 m-2s-1) of soybean plants at R3-R5 stage on infested, non-infested caged and non-infested uncaged control \pm SEM after 5 and 10 days after infestation (DAI) with Tetranychus urticae. Means followed by the same letter within a day are not significantly different by $t$ test $(\mathrm{P}>0.05)$.

Table 2 - Number of Tetranychus urticae \pm SEM 5 and 10 days after mite infestation (DAI) on soybean plants at $\mathrm{R}_{3}-\mathrm{R}_{5}$ stage.

\begin{tabular}{cc}
\hline DAI & Number of mites/cm $\mathbf{c m}^{2}$ \\
\hline 5 & $0.62 \pm 0.53 \mathrm{a}$ \\
10 & $1.88 \pm 0.53 \mathrm{a}$ \\
\hline
\end{tabular}

Means followed by the same letter are not significantly different by t test $(\mathrm{P}>0.05)$.

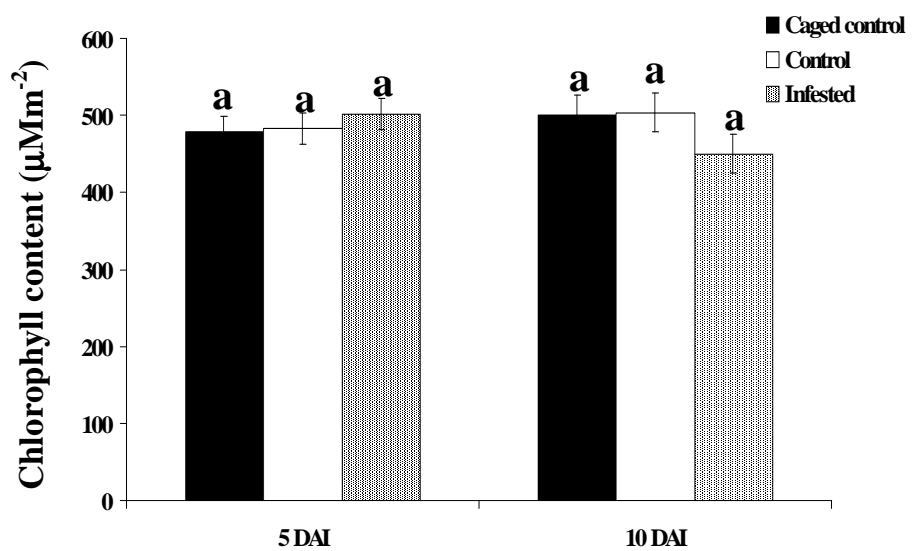

Figure 5 - Chlorophyll content $(\mu \mathrm{Mm}-2)$ of soybean plants at R3-R5 stage on infested, noninfested caged and non-infested uncaged control \pm SEM after 5 and 10 days after infestation (DAI) with Tetranychus urticae. Means followed by the same letter within a day are not significantly different by $t$ test $(\mathrm{P}>0.05)$. 


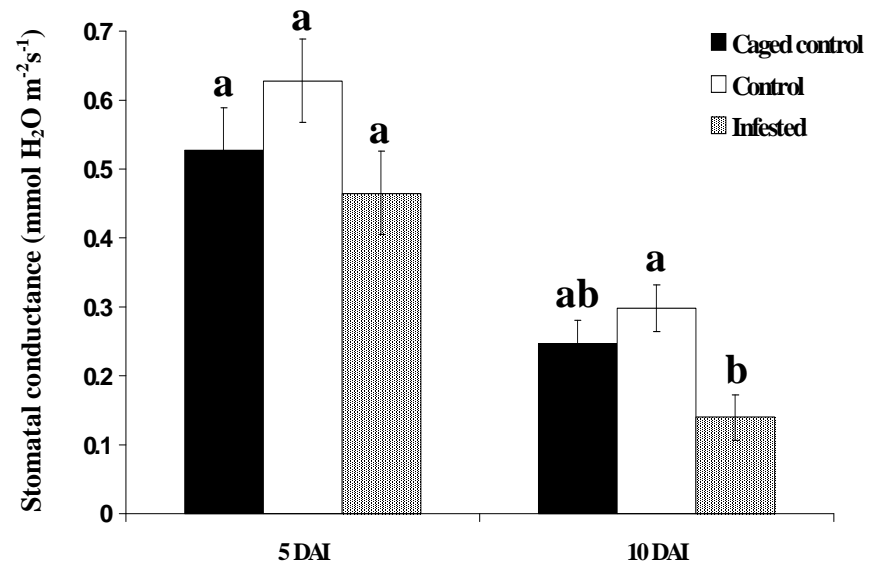

Figure 6 - Stomatal conductance (mmol H2O m-2s-1) of soybean plants at R3-R5 stage on infested, non-infested caged and non-infested uncaged control \pm SEM after 5 and 10 days after infestation (DAI) with Tetranychus urticae. Means followed by the same letter within a day are not significantly different by $t$ test $(\mathrm{P}>0.05)$.
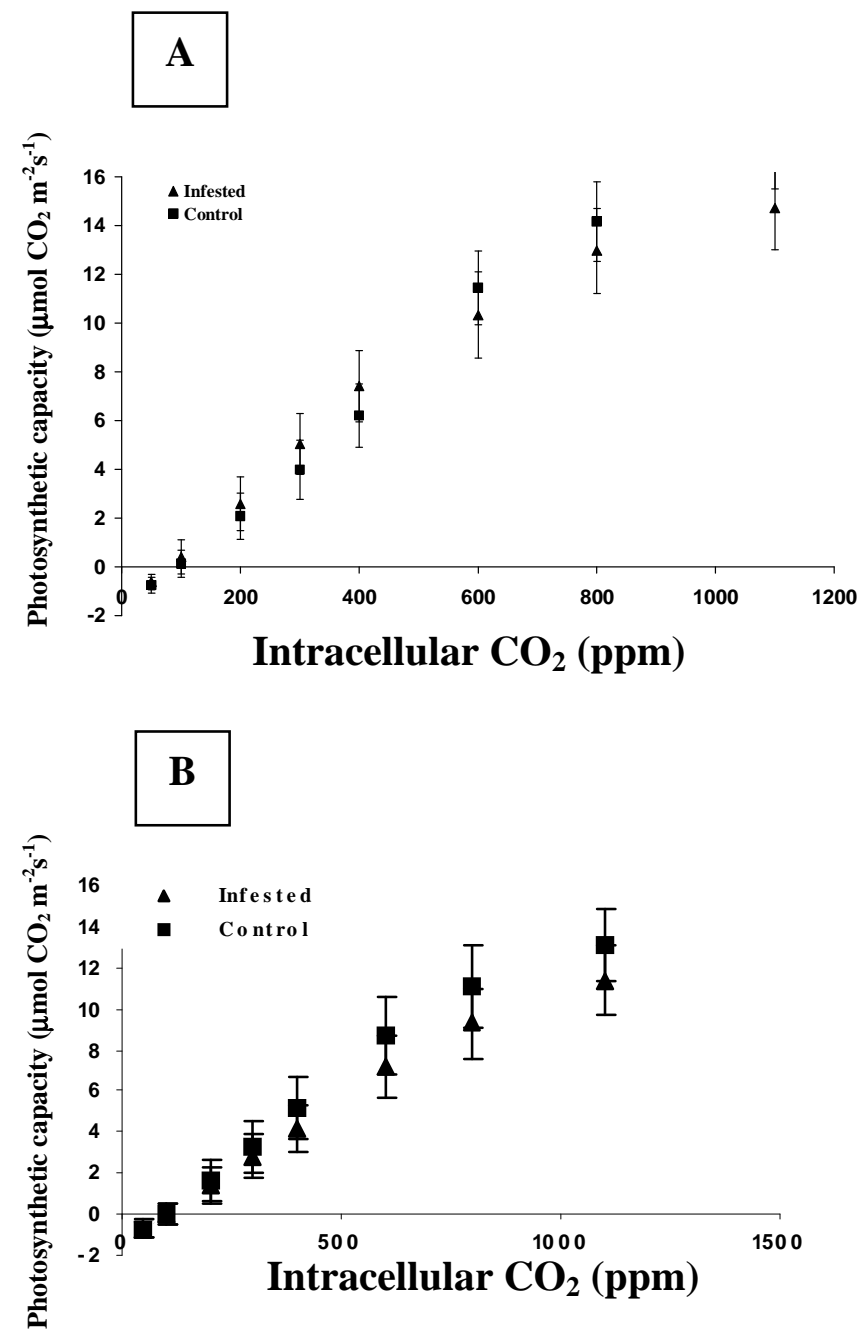

Figure 7 - Relantionships between intracellular CO2 levels (ppm) and photosynthetic rates ( $\mu$ mol $\mathrm{CO} 2 \mathrm{~m}-2 \mathrm{~s}-1)$ of control and infested soybean leaflets at 9 (A) and 12 (B) days after Tetranychus urticae infestation. 
Table 3 - Fluorescence induction transients measurements of mite-infested and control soybean plants at $V_{5}$ stage \pm SEM 12 days after infestation (DAI).

\begin{tabular}{ccc}
\hline \multirow{2}{*}{ Fluorescence } & 12 DAI \\
\cline { 2 - 3 } & Infested & Control \\
\hline Fo & $507.9 \pm 9.44 \mathrm{a}$ & $506.7 \pm 9.44 \mathrm{a}$ \\
Fm & $821 \pm 87.4 \mathrm{a}$ & $759.3 \pm 87.4 \mathrm{a}$ \\
Fo' & $351.7 \pm 9.21 \mathrm{a}$ & $350.5 \pm 9.21 \mathrm{a}$ \\
Fm' & $543.8 \pm 18.94 \mathrm{a}$ & $544.8 \pm 18.94 \mathrm{a}$ \\
Fs & $491.6 \pm 18.83 \mathrm{a}$ & $492.6 \pm 18.83 \mathrm{a}$ \\
Fv/Fm & $0.3912 \pm 0.0344 \mathrm{a}$ & $0.3317 \pm 0.0344 \mathrm{a}$ \\
Fv'/Fm' & $0.2933 \pm 0.0067 \mathrm{a}$ & $0.2967 \pm 0.0067 \mathrm{a}$ \\
qP & $0.2284 \pm 0.0161 \mathrm{a}$ & $0.2273 \pm 0.0161 \mathrm{a}$ \\
qN & $0.4955 \pm 0.0599 \mathrm{a}$ & $0.413 \pm 0.0599 \mathrm{a}$ \\
ETR & $17 \pm 0.98 \mathrm{a}$ & $17.04 \pm 0.98 \mathrm{a}$ \\
\hline
\end{tabular}

Mean $( \pm$ SEM) followed by the same letter within a line are not significantly different by $t$ test $(\mathrm{P}>0.05)$.

Table 4 - Fluorescence induction transients measurements of mite-infested and control soybean plants at $R_{5}$ stage \pm SEM 10 days after infestation (DAI).

\begin{tabular}{lcc}
\hline Fluorescence & & 10 DAI \\
\cline { 2 - 3 } & Infested & Caged control \\
\hline Fo & $391.40 \pm 51.29 \mathrm{a}$ & $465.78 \pm 51.29 \mathrm{a}$ \\
Fm & $1194.53 \pm 76.79 \mathrm{a}$ & $1136.83 \pm 76.79 \mathrm{a}$ \\
Fo' & $319.17 \pm 8.79 \mathrm{a}$ & $320.16 \pm 8.79 \mathrm{a}$ \\
Fm' & $597.73 \pm 13.47 \mathrm{a}$ & $584.37 \pm 13.47 \mathrm{a}$ \\
Fs & $405.33 \pm 15.22 \mathrm{a}$ & $410.79 \pm 15.22 \mathrm{a}$ \\
Fv/Fm & $0.6040 \pm 0.0441 \mathrm{a}$ & $0.5645 \pm 0.044 \mathrm{a}$ \\
Fv'/Fm' & $0.3871 \pm 0.0209 \mathrm{a}$ & $0.3757 \pm 0.0209 \mathrm{a}$ \\
qP & $0.5704 \pm 0.0363 \mathrm{a}$ & $0.5479 \pm 0.0363 \mathrm{a}$ \\
qN & $0.5289 \pm 0.0314 \mathrm{a}$ & $0.5559 \pm 0.0314 \mathrm{a}$ \\
ETR & $56.59 \pm 6.23 \mathrm{a}$ & $52.75 \pm 6.23 \mathrm{a}$ \\
\hline
\end{tabular}

Mean ( \pm SEM) followed by the same letter within a line are not significantly different by $\mathrm{t}$ test $(\mathrm{P}>0.05)$.

The plant physiological response to a biotic stress is crucial to establish the economic thresholds that are the keystone of any decision making on pest management. Arthropods that trigger the same plant physiological response of host might be grouped in the guilds and then multiple species economic thresholds can be developed. This is an important step on insect pest management development since most of the situations growers are coping with has more than one arthropod pest species present. Present data showed that the twospotted spider mite injury did not cause any mesophyll limitation to photosynthesis. The photosynthetic impairment was associated to stomatal limitations in $\mathrm{CO}_{2}$ availability. This is different of other insect guilds such as defoliators where stress on plant physiology is restricted to leaf area index reduction (Peterson, 1995) or sucking arthropods that feed on specific tissue impairing biochemical mechanism for restoring chlorophyll (Macedo et al., 2003). However, T. urticae might be grouped with other mite species and any other arthropods that have stomatal closure as the only major photosynthetic impairment.

The combination of gas exchange, ACi-curve, fluorescence data offered important insights into the impact of $T$. urticae on soybean physiology and showed that even in small number twospotted spider mite might be a serious pest, at least under the circumstances in which photosynthesis capacity was limiting to crop yield. Also, when attacked by an herbivore, a plant might suffer not only the direct fitness consequences of tissue 
injury but also a loss of competitive abilities. Besides, some direct defenses may require large investments of resources that could otherwise be used for growth, suggesting that plants face tradeoffs in the allocation of resources to traits for resistance and competition (Herms and Matson, 1992). Consequently, future studies must address physiological responses at higher levels of organization (plant canopy, for example) since the impact of $T$. urticae on crop yield might go beyond the photosynthetic capacity impairment.

\section{ACKNOWLEDGMENTS}

Authors acknoledge J. E. Specht from the Department of Agronomy and Horticulture, University of Nebraska, Lincoln for opening his experimental field plots for the realization of the field experiment. The grant support for A. F. Bueno was provided by both the Fulbright Commission's Council for International Exchange of Scholars and CAPES, Brazil.

\section{RESUMO}

O ácaro-rajado, Tetranychus urticae Koch é uma praga comum em plantas de soja. Para elucidar a interação entre o artrópode e a planta no sistema soja-ácaro, a fluorescência, as respostas fotossintéticas em diferentes concentrações internas de $\mathrm{CO}_{2}$ e o conteúdo de clorofila foram avaliados. Observou-se redução na capacidade fotossintética das plantas infestadas e o fechamento dos estômatos foi a principal causa dessa redução. As plantas infestadas não mostraram redução no conteúdo de clorofila. Também, nenhuma diferença foi encontrada na leitura de fluorescência, o que mostra que a injúria causada pelo ácaro não prejudica a coleta de luz nem o transporte de elétrons. Estes resultados mostram que $T$. urticae pode ser uma praga séria na cultura da soja mesmo em baixas infestações, principalmente nas situações em que a fotossíntese é fator determinante na produção.

\section{REFERENCES}

Bondada, B. R.; Oosterhuis, D. M.; Tugwell, N. P.; Kim, K. S. (1995), Physiological and cytological studies of two-spotted spider mite, Tetranychus urticae Koch, injury in cotton. Southwestern Entomologist, 20, 171-180.

Brito, R. M.; Stern, V. M.; Sanches, F. V. (1986), Physiological response of cotton plants to feeding of three Tetranychus spider mite species (Acari: Tetranychidae). Journal of Economic Entomology, 79, 1217-1220.

Burd, J. D.; Elliot, N. C. (1996), Changes in chrophyll $a$ fluorescence induction kinetics in cereals infested with Russian wheat aphid (Homoptera: Aphidae). Journal of Economic Entomology, 89,1332-1337.

Campbell, R. J.; Mobley, K. N.; Marini, R. P. (1990), Growing conditions influence mite damage on apple and peach leaves. HortScience, 25, 445-448.

Candolfi, M. P.; Roller, E. F.; Wermelinger, B. (1992), Influence of two-spotted spider mite, Tetranychus urticae, on gas exchange of Pinot noir grapevine leaves. Vitis, 31, 205-212.

DeAngelis, J. R., Berry, E.; Krantz, G. W. (1983), Photosynthesis, leaf conductance and leaf chlorophyll content in spider mite (Acari: Tetranychidae)-injured peppermint leaves. Environmental Entomology, 12, 345-348.

Farquar, G. D.; von Caemmerer, S.; Berry, J. A. (1980), A biochemical model of photosynthetic $\mathrm{CO}_{2}$ assimilation in leaves of $\mathrm{C}_{3}$ species. Planta, 149, 7890.

Ferree, D. C.; Hall, F. R. (1980), Effects of soil water stress and two-spotted spider mites on net photosynthesis and transpiration of apple leaves. Photosynthesis Research, 1, 189-197.

Haile, F. J.; Higley, L. G. (2003), Changes in soybean gas-exchange after moisture stress and spider mite injury. Environmental Entomology, 32, 433-440.

Herms, D. A.; Mattson, W. J. (1992), The dilema of plants: to growth or defend. Quartery Review of Biology, 67, 323-340.

Hislop, R. G.; Jeppson, L. R. (1976), Morphology of the mouth parts of several species of phytophagous mites. Annals of the Entomological Society of America, 69, 1125-1135.

Klubertanz, T. H.; Pedigo, L. P.; Carlson, R. E. (1991), Impact of fungal epizootics on the biology and management of the two-spotted mite (Acari: Tetranychidae) in soybean. Environmental Entomology, 20, 731-735. 
Jeppson, L.R., Keifer, H. H.; Baker, E. W. (1975), Mites injurious to economic plants. University of California Press, Berkeley.

Lakso, A. N.; Mattii, G. B.; Nyrop, J. P.; Denning, S. S. (1996), Influence of European red mite on leaf and whole-cannopy carbon dioxide exchange, yield, fruit size, quality, and return cropping in 'Starkrimson Delicious' apple trees. Journal of the American Society for Horticultural Science, 121, 954-958.

Macedo, T. B.; Bastos, C. S.; Higley, L. G.; Ostlie, K. R.; Madhavan, S. (2003), Photosynthetic response of soybean to soybean aphid (Homoptera: Aphidae) Injury. Journal of Economic Entomology, 96, 188193.

Park, Y.; Lee, J. (2002), Leaf cell and tissue damage of cucumber caused by twospotted spider mite (Acari: Tetranychidae). Journal of Economic Entomology, 95, 952-957.

Peterson, R. K. D.; Higley, L. G. (1993), Arthropod injury and plant gas exchange: Current understanding and approaches for synthesis. Entomology (Trends in Agricultural Science), 1, 93-100.

Peterson, R. K. D.; Higley, L. G. (1996), Temporal changes in soybean gas exchange following simulated insect defoliation. Agronomy Journal, 88, 550-554.

Peterson, R. K. D.; Higley, L. G. (2001), Iluminating the Black Box: The relationship between injury and yield. In-Biotic stress and yield loss, eds. R.K.D. Peterson. and L.G. Higley. CRC Press LLC, Boca Raton, Florida, pp. 1-12.

Peterson, R. K. D.; Higley, L. G.; Barrigosi, J. A. (1998), Mexican bean beetle (Coleoptera: Coccinellidae) injury affects photosynthesis of Glycine max and Phaseolus vulgaris. Environmental Entomology, 27, 373-381.
Ratcliffe, R. H.; Bissell, T. H.; Bickley, W. E. (1960), Observations on soybean insects in Maryland. Journal of Economic Entomology, 53, 131-133.

Rilling, G.; During, H. (1990), Structure and function of grapevine leaves (Vitis vinifera L.) as affected by the European red mite (Pononychus ulmi Koch). Vitis, 29, 27-42.

Sadras, V. O.; Wilson, L. J. (1997), Growth analysis of cotton crops infested with spider mites: I. Light interception and radiation-use-efficiency. Crop Science, 37 481-491.

Sanches, F. V.; Wyman, J. A.; Ting, I. P. (1979), Morphological responses of strawberry leaves to infestation of twospotted spider mite. Journal of Economic Entomology, 72, 710-713.

Sances, F. V.; Toscano, N. C.; Hoffmann, M. P.; Lapré, L. F.; Johnson, M. W.; Bailey, J. B. (1982a), Physiological responses of avocado leaves to avocado brown mite feeding injury. Environmental Entomology, 11, 516-518.

Sanches, F. V.; Toscano, N. C.; Oatman, E. R.; Lapré, L. F.; Johnson, M. W.; Voth, V. (1982b), Reductions in plant process by Tetranychus urticae (Acari: Tetranychidae) feeding on strawberry. Environmental Entomology, 11, 733-737.

SAS Istitute. (2001), SAS user's guide: statistics, version $8 e$. SAS Institute, Cary, NC.

Welter, S.C.; Farnham, D. S.; McNally, P. S.; Freeman, R. (1989), Effect of Willamette mite and Pacific spider mite (Acari: Tetranychidae) on grape photosynthesis and stomatal conductance. Environmental Entomology, 18, 953-957.
Received: July 02, 2007; Revised: October 22, 2007; Accepted: December 23, 2008 